\title{
Assessment of Risk Factors in Patients with Chronic Hepatitis B
}

\author{
Professor Sorush Niknamian \\ Member of Federal Health Professionals, Military Medicine, US Army \\ E-mail: sorush.niknamian@ mycampus.apus.edu
}

\begin{abstract}
Background: Hepatitis B virus infection and its complications are major health problems. The aim of this study were to investigate risk factors in patients with chronic hepatitis B.

Methods: This cross-sectional study was performed on 174 patients with chronic hepatitis B who referred to the Shahid Mohammadi hospital in the city of Bandar Abbas, Iran. Information was collected through a questionnaire.

Results: 174 persons (97 males, 77 females) with a mean age of 42.96 years. There was no significant relationship between the risk of having disease with gender, age, weight, height, waist circumference, hip circumference, BMI and WHR $(\mathrm{P}>0.05)$. The frequency of exposure to risk factors are as follows: such as history of hairdressers, vaccination, contact with suspected HBV persons, Family history of HBV positive in patients had higher prevalence than other groups.
\end{abstract}

Conclusion: It seems to be more important to pay attention to lifestyles, jobs, and cultural themes of Iranian people that predispose people to risk factors so as to implement measures to control HBV spread. Also, awareness and social-health education in order to avoid unprotected sexual contact with an infected partner can be highly effective according to the high levels of hepatitis B infection among married persons. Despite existence of a long list of risk factors, various epidemiological studies with alternative methodologies along with meta-analysis of risk factors in each separate area seems to be helpful in collecting information about transmission. 
Keywords: Chronic hepatitis B; Risk Factors; Prevalence; Iran

\section{Introduction}

Hepatitis B virus (HBV) infection is a major public health problem and it is estimated that between 350 and 400 million people worldwide suffering from chronic hepatitis B (CHB) infection. ${ }^{1,2}$ Annually, about one million people die from chronic hepatitis B virus infection. ${ }^{3,4}$ Hepatitis B carriers are reported from $0.1 \%$ to $20 \%$ in different regions of the world, that the highest prevalence of chronic hepatitis B is in the Middle East and Asia. ${ }^{5}$ The prevalence of chronic hepatitis B in Iran is between $2 \%$ and $7 \%,{ }^{6}$ which is among the hypernomedema and hypovomidemia areas. ${ }^{7}$ Chronic hepatitis B along with hepatic cirrhosis and hepatocellular carcinoma (HCC) causes a mortality of between 0.5 and 1.3 million per year. ${ }^{8.9}$ In Iran, 1.5 million people are infected with hepatitis B, of which $15-40 \%$ are prone to cirrhosis of the liver or hepatocellular carcinoma in the future. ${ }^{10}$ In Iran, $46 \%$ of patients with hepatocellular carcinoma and 51\% with cirrhosis have been reported as positive HBsAg. ${ }^{11}$ In addition, hepatitis B virus is the most common cause of chronic hepatitis (70-80\%) in the country. ${ }^{2}$ To have an effective strategy to prevent hepatitis B, knowing the most common means of transmission in every country is essential, since many people with hepatitis are asymptomatic, the importance of risk control programs are further realized. Despite the availability of an effective vaccine, hepatitis B virus infection remains an important health problem. ${ }^{11}$

Blood and blood products are the principal ways of HBV transmission the same as hepatitis C virus (HCV) and human immunodeficiency virus (HIV). Vertical and horizontal transmissions are the significant routes of intra-familial transmission of $\mathrm{HBV}^{12-14}$ in hyperendemic areas of the world. Sexual contact is the main transmission reason of Hepatitis B virus in Western Europe and North America ${ }^{15}$. Minor injuries by needles in health staff, shared needles, haemodialysis, dental 
surgery, transmission of blood products, bloodletting, ear and nose piercing practices, tattooing and contact with body fluid or mucosa of HBV carriers (e.g. staff in clinical laboratories) have been related with increased risk of transmission ${ }^{15}$. However, about $30 \%$ of hepatitis B cannot be associated with a distinguishable risk factor in the adults ${ }^{16}$.

In the Islamic Republic of Iran, $46 \%$ of patients with hepatocellular carcinoma and 51\% of who with cirrhosis are reported to be $\mathrm{HBsAg}$ positive ${ }^{17}$. In addition, HBV is recognized as the most frequent reason (70\%-80\%) of chronic hepatitis in the country. Hepatitis B virus (HBV) is a prime health problem in spite of the availability of a practicable vaccine. Surely, finding the key routes of hepatitis transmission from the point of prevention in every country, is of great importance. Many hepatitis patients do not show any symptoms ${ }^{18}$. Considering the potency of HBV elimination, finding the routes of transmission and knowing the target population on whom we should have put a great emphasis are the health priorities to ${ }^{19,20}$. The purpose of this study were to investigate risk factors in patients with chronic hepatitis B and their relation with the incidence of disease.

\section{Patients and Methods}

This cross-sectional study was conducted during 2017 to 2018 on 174 HBV patients who came to Shahid Mohammadi hospital hepatitis clinic in the city of Bandar Abbas, Iran.

We also use different methods to identification of $\mathrm{HBV}$ in patient, that included: routine screening, blood donation, signs and symptoms, positive cases in family, screening tests due to the increasing ALT and screening tests before surgery.

Information was collected by interviewing patients by researcher-made questionnaire. A questionnaire including demographic and socioeconomic data and risk factors of hepatitis B 
including age, gender, level of education, job, jail history, history of contact with suspected HBV persons, having extramarital sexual relationship, and etc. were collected.

Anthropometric information was measured including: weight, height, waist and hip via the following method. The body weight was measured using a Seca digital scale and accurately of 0.1 $\mathrm{kg}$ with minimum dress and no shoe. Height was also measured by tape meter and with an accuracy of $0.1 \mathrm{~cm}$ in standing position, in which the shoulders of the individual were in normal position and without footwear, and the body mass index was calculated by dividing the weight $(\mathrm{kg})$ into square of height $(\mathrm{m})$. Waist circumference was measured at the narrowest waist area and hip circumference in the most prominent hips area with minimum dress and with a tape meter and accurately $0.1 \mathrm{~cm}$. Waist-hip ratio (WHR) index was calculated by dividing waist circumference to hip circumference.

Statistical analysis was performed using the SPSS, version 21, software package (SPSS, Inc., Chicago, IL). Data are reported as mean \pm standard deviation or number (\%) for continuous and categorical data, respectively. Statistical analysis were also performed using $\chi^{2}$ and $T$ test for categorical variables. $\mathrm{P}$ values less than 0.05 were considered statistically significant.

\section{Results}

During the period of this study from 2017 to 2018 , total of 174 patients with chronic hepatitis B were identified in our center. The mean age of subjects was $42.96 \pm 15.33$ years, 97 (55.7) were men and 77 (44.3) were women. The age frequency distribution of patients with chronic hepatitis B showed that the prevalence of this disease was highest in the age group of 25-34 and at the age of 34-44 (Table 2). The results of comparing the place of residence, education level, marital status, profession, nationality and indigenous of patients are summarized in Table 1. 
According to the results of independent t-test, there was no significant difference between the male and female in mean of weight, height, waist circumference, hip circumference, BMI and WHR $(\mathrm{P}>0.05)$ (Table 3). The highest rate of disease was observed in the group with BMI of 18.5-24.9, and the highest incidence of chronic hepatitis B was observed in women and men with WHR> 0.85 and 0.95 , respectively (Table 4). The results showed that there was no significant relationship between the disease and anthropometric indices $(\mathrm{P}>0.05)$.

The descriptive characteristics of subjects such as intravenous drug use, rpregnancy, vertical transmission, family history of $\mathrm{HBV}$ positive in patients, history dialises, jail, tattooing, piercing, history of hairdressers, endoscopy, colonoscopy, surgery, dentist visit, water pipe, smoking, alcohol cosumpsion, vaccination history, hospitalization, HIV disease in patients at the same time, HCV disease in patients at the same time, family history of HIV positive in patients, family history of HCV positive in patients, phlebotomy (hejamat), needle stick, addiction, health workers, contact with suspected HBV persons, blood transfusion and blood products history, injection drug addicts and Unsafe sexual practices and dubious were found as risk factors in univariate analysis (Table 5).

\section{Discussion}

Hepatitis B virus (HBV) infection is the most common form of chronic hepatitis and it is the eminent cause of chronic liver disease and liver-related death ${ }^{21}$. The prevalence of hepatitis B is $5 \%$ in the world which makes it one of the most prevalent infectious diseases. HBV is transmitted through both vertical and horizontal routes. Nowadays the horizontal routes are much more importantm, however vertical routes are reported as a very common route in $\operatorname{Iran}^{10}$. Vaccination is the most efficient method to prevent HBV infection and the most members of the World Health Organization have performed universal HBV vaccination programs. In a study 
conducted in Iran, the general prevalence rate showed no significant decrease before and after vaccination of children, however in the age group 2-14 years the rate decline significantly from $1.3 \%$ to $0.8 \%$ during 8 years ${ }^{22}$. Our results show the similar percentage, and the rate of CHBV was lower in children.

The prevalence of HBV infection in this study is quite different among nations and indigenous people, and they were higher in Iranian and indigenous people compared to non- Iranian and nonindigenous people. Males were at higher risk of HBV infection compared to females. It has been suggested that estrogen may play an important role in the protection and resistance of hepatic cells against the development of chronic liver disease ${ }^{22}$. In addition, the association between male gender and hepatitis B is probably the result of greater exposure to risky sexual behavior among men, a hypothesis reinforced by the higher prevalence of other sexually transmitted diseases among these individuals ${ }^{23}$.

Lower education was related to the presence of HBV infection. The association between hepatitis B and lower education has been previously reported in international studies. Schooling is one indicator of socioeconomic status and these results probably reflect that a greater exposure to HBV occurs in situations including poverty and less access to information regarding preventive measures $^{24}$.

The factors associated with obesity in chronic hepatitis B patients are not related to the progression of the disease. High BMI (> $25 \mathrm{~kg} / \mathrm{m} 2)$ is an independent risk factor for the development of $\mathrm{HCC}$ in people with chronic hepatitis $\mathrm{C}(\mathrm{CHC})^{25}$. Obesity is associated with recurrence of $\mathrm{HCC}$ and liver-related complications in $\mathrm{CHC}_{\text {patients }}{ }^{26}$. On the other hand obesity is not a risk factor for HCC development in CHB patients ${ }^{27}$. In study on the $1543 \mathrm{HBV}$-related HCC patients, obesity is not associated with mortality in patients treated with surgical removal of HBV-related $\mathrm{HCC}^{28}$. In 
this study, BMI and WHR were measured and statistical analysis showed they have no positive effect on the incidence of chronic hepatitis B infection. The highest incidence of chronic hepatitis B was in people with normal BMI and WHR.

Our results show that there were no cases of hepatitis B in history of HCV disease in patients at the same time and Family history of HIV positive in patients.

Recognizing risk factors for $\mathrm{HBV}$ infection is crucial for development of control measures. Different studies have shown that sexual and injection exposures are the main risk factors of HBV infection among adolescents and adults in countries of low or intermediate endemicity ${ }^{29-32}$. In contrast, in our study sexual exposure and reusing syringes among drug addicts were ranked among the least probable risk factors of infection. This most probably doesn't exactly reflect the reality as much as it reflects the conservative nature of our society. The major sources of infection in our study were history of hairdressers, vaccination history and contact with suspected HBV persons.

Some groups, such as health care workers, especially surgeons, nurses, dentists, policemen, barbers, and drivers are at higher risk of acquiring HBV infection in our region ${ }^{23}$. In this study jobless and self-employee were found to be associated with higher risk of being chronically infected with hepatitis B virus. Certain jobs, lifestyles and cultural matters seem to be independent risk factors for $\mathrm{HBV}$ infection ${ }^{33}$.

In Mexico, tattooing is considered among the risk factors ${ }^{34}$. In gypsy communities, it is suggested that tattooing could be a significant factor in relation to the transmission of hepatitis $\mathrm{B}^{35}$. In our study, it was found as a risk factor in $1.7 \%$ of patients.

Familial contact with $\mathrm{HBV}$-infected patients play an significant role in horizontal HBV transmission, as the result of our study show $26.4 \%$ of participant had a history of HBV positive 
in the patient's family. In Romania and in Thailand the most important risk factor for HBV infection was contact with an infected person. In Greece, one of the major independent risk factors was interfamilial exposure ${ }^{36-38}$.

The main recommendation of this study is to have a governmental education and media campaign about the risks of $\mathrm{HBV}$ infection, routes of transmission and methods of protection. The government can make use of the health and media experts across the country to formulate new plans for the educational and media campaign. Furthermore, increasing HBV vaccination of high risk groups, screening HBV infection during pregnancy, and surveillance of hepatitis B infected individuals will further decrease the prevalence of the disease in Iran.

\section{Conclusion}

As identified in this study, there is a requirement for increasing the awareness and prevention of contracting and transmitting $\mathrm{HBV}$ infection. Also, there is a need to incorporate screening for $\mathrm{HbsAg}$ and vaccination against $\mathrm{HBV}$. We highly recommend a meta-analysis of risk factors in each separate area that seems to be helpful and useful in providing and preparing data about transmission routes and surveillance of hepatitis B infection.

Conflict of Interest: There are no conflicts of interest. 


\section{References}

1. Liaw YF, Chu CM. Hepatitis B virus infection. Lancet. 2009;373:582-92. doi: 10.1016/S0140-6736(09)60207-5. PubMed PMID: 19217993.

2. Abolghasemi S, Sali S, Kiani P. Assessment of Risk Factors in Patients with Chronic Hepatitis B Referred to Dr. Labbafi Nejad's Hospital Hepatitis Clinic 2012-2014. Novelty in Biomedicine. 2017;5:37-42.

3. Wright TL. Introduction to chronic hepatitis B infection. Am J Gastroenterol. 2006; 101: 1-6. doi: 10.1111/j.1572-0241.2006.00469.x. PubMed PMID: 16448446.

4. Esmaeelzadeh A, Saadatnia H, Memar B, Amirmajdi EM, Ganji A, Goshayeshi L, et al. Evaluation of serum HBV viral load, transaminases and histological features in chronic HBeAg-negative hepatitis B patients. Gastroenterol Hepatol Bed Bench. 2017;10:39-43. PubMed Central PMCID: PMC5346823.

5. Alter MJ, Mast EE. The epidemiology of viral hepatitis in the United States. Gastroenterol Clin N. 1994;23:437-55. PubMed PMID: 7989088.

6. World Health Organization. Introduction of hepatitis B vaccine into childhood immunization services: Management guidelines, including information for health workers and parents. 2001.

7. Poorolajal J, Majdzadeh R. Prevalence of chronic hepatitis B infection in Iran: a review article. J Res Med Sci. 2009;14:249-58. PubMed Central PMCID: PMC3129112.

8. Lavanchy D. Hepatitis B virus epidemiology, disease burden, treatment, and current and emerging prevention and control measures. J Viral Hepatitis. 2004;11:97-107. PubMed PMID: 14996343. 
9. Alavian SM, Imanieh MH, Imanieh MH. Predictive factors in the incidence of cirrhosis in chronic hepatitis B virus infections. Hepat Mon. 2016;16:e34790. PubMed Central PMCID: PMC4912694.

10. Alavian SM, Hajarizadeh B, Ahmadzad-Asl M, Kabir A, Lankarani KB. Hepatitis B Virus Infection in Iran: A Systematic Review. Hepat Mon. 2008;8:281-94.

11. Alavian SM, Gooya MM, Hajarizadeh B, Esteghamati AR, Moeinzadeh AM, Haghazali M, et al. Mass vaccination campaign against hepatitis B in adolescents in Iran: estimating coverage using administrative data. Hepat Mon. 2009;9:189-95.

12. Joshi N, Yr N, Kumar A. Age related seroprevalence of antibodies to hepatitis A virus in Hyderabad, India. Tropical gastroenterology: official journal of the Digestive Diseases Foundation. 1999;21(2):63-5.

13. Werner G, Frösner G, Fresenius K. Prevalence of serological hepatitis A and B markers in a rural area of northern Zaire. The American journal of tropical medicine and hygiene. $1985 ; 34(3): 620-4$.

14. Lionis C, Frangoulis E, Koulentakis M, Biziagos E, Kouroumalis E. Prevalence of hepatitis $\mathrm{A}, \mathrm{B}$, and $\mathrm{C}$ markers in school children of a rural area of Crete, Greece. European journal of epidemiology. 1997;13(4):417-20.

15. Nair S, Perrillo R. Hepatitis B and D: In: Zakim D, Boyer TO, Hepatology, editors. At extbook of liver disease 4th ed Philadelphia: Saunders. 2003:993.

16. Shapiro CN. Epidemiology of hepatitis B. The Pediatric infectious disease journal. $1993 ; 12(5): 433-7$.

17. Alizadeh A, Ranjbar M, Ansari S, MirArab A, Alavian S, Mohammad K, et al. Seroprevalence of hepatitis B in Nahavand, Islamic Republic of Iran. 2006. 
18. Alavian SM, Gooya MM, Hajarizadeh B, Esteghamati A-R, Moeinzadeh AM, Haghazali $\mathrm{M}$, et al. Mass vaccination campaign against hepatitis B in adolescents in Iran: estimating coverage using administrative data. Hepat Mon. 2009;9(3):189-95.

19. Shahnaz S, Reza B. Risk factors in chronic hepatitis B infection: a case-control study. Hepatitis Monthly. 2005;2005(4, Autumn):109-15.

20. Mendoza Ticona A, Samalvides Cuba F. Transmisión de los virus de la inmunodeficiencia adquirida, hepatitis B y hepatitis C por exposiciones laborales en trabajadores de salud: aspectos de profilaxis pre y post exposición. Revista Medica Herediana. 2005;16(4):27684.

21. Ezechi OC, Kalejaiye OO, Gab-Okafor CV, Oladele DA, Oke BO, Musa ZA, et al. Seroprevalence and factors associated with Hepatitis B and C co-infection in pregnant Nigerian women living with HIV infection. The Pan African medical journal. 2014;17:197. PubMed PMID: 25396023. Pubmed Central PMCID: PMC4229000. Epub 2014/11/15. Eng.

22. Baig S. Gender disparity in infections of Hepatitis B virus. J Coll Physicians Surg Pak. 2009;19(9):598-600.

23. Da Ros CT, da Silva Schmitt C. Global epidemiology of sexually transmitted diseases. Asian journal of andrology. 2008;10(1):110-4.

24. Torres JR. Hepatitis B and hepatitis delta virus infection in South America. Gut. 1996;38 Suppl 2:S48-55. PubMed PMID: 8786054. Pubmed Central PMCID: PMC1398044. Epub 1996/01/01. Eng.

25. Ohki T, Tateishi R, Sato T, Masuzaki R, Imamura J, Goto T, et al. Obesity is an independent risk factor for hepatocellular carcinoma development in chronic hepatitis $\mathrm{C}$ 
patients. Clin Gastroenterol H. 2008;6:459-64. doi: 10.1016/j.cgh.2008.02.012. PubMed PMID: 18387499.

26. Mathur A, Franco ES, Leone JP, Osman-Mohamed H, Rojas H, Kemmer N, et al. Obesity portends increased morbidity and earlier recurrence following liver transplantation for hepatocellular carcinoma. HPB. 2013;15:504-10. doi: 10.1111/j.1477-2574.2012.00602.x. PubMed PMID: 23750492. PubMed Central PMCID: PMC3692019.

27. Chen CJ, Yang HI, Su JUN, Jen CL, You SL, Lu SN, et al. Risk of hepatocellular carcinoma across a biological gradient of serum hepatitis B virus DNA level. Jama. 2006;295:65-73. doi: 10.1001/jama.295.1.65. PubMed PMID: 16391218.

28. Wang H, Yang J, Zhang X, Yan L, Yang J. Liver resection in hepatitis B-related hepatocellular carcinoma: clinical outcomes and safety in overweight and obese patients. PloS one. 2014;9:e99281. doi: 10.1371/journal.pone.0099281. PubMed PMID: 24914932. PubMed Central PMCID: PMC4051674.

29. Goldstein ST, Alter MJ, Williams IT, Moyer LA, Judson FN, Mottram K, et al. Incidence and risk factors for acute hepatitis B in the United States, 1982-1998: implications for vaccination programs. Journal of infectious diseases. 2002;185(6):713-9.

30. Shepard CW, Simard EP, Finelli L, Fiore AE, Bell BP. Hepatitis B virus infection: epidemiology and vaccination. Epidemiologic reviews. 2006;28(1):112-25.

31. Souto FJ, Espírito Santo GA, Philippi JC, Pietro BR, Azevedo RB, Gaspar A. Prevalence of and factors associated with hepatitis B virus markers in a rural population in central Brazil. Revista Panamericana de Salud Pública. 2001;10(6):388-94.

32. Pereira LM, Martelli CM, Merchán-Hamann E, Montarroyos UR, Braga MC, de Lima ML, et al. Population-based multicentric survey of hepatitis B infection and risk factor 
differences among three regions in Brazil. The American journal of tropical medicine and hygiene. 2009;81(2):240-7.

33. SeyedMohammad M. Risk factors of hepatitis B infection: Health policy makers should be aware of their importance in each community. Hepatitis monthly. 2011;2011(4, Apr):2389.

34. Tanaka J. Hepatitis B epidemiology in Latin America. Vaccine. 2000;18:S17-S9.

35. Rosario PM, Arnedo A, Montaner M, Prieto P, García J, Izuel M, et al. [Epidemic outbreak of hepatitis B from the tattoo in gypsy families]. Revista espanola de salud publica. 1995;70(1):63-9.

36. Ion-Nedelcu N, Mihăileanu C, Dobrescu A. [The risks of transmitting viral hepatitis in a section of the city of Bucharest]. Revista de igiena, bacteriologie, virusologie, parazitologie, epidemiologie, pneumoftiziologie Bacteriologia, virusologia, parazitologia, epidemiologia. 1988;34(2):155-62.

37. Nuchprayoon T, Chumnijarakij T. Risk factors for hepatitis B carrier status among blood donors of the National Blood Center, Thai Red Cross Society. Southeast Asian J Trop Med Public Health. 1992;23(2):246-53.

38. Gogos C, Fouka K, Nikiforidis G, Avgeridis K, Sakellaropoulos G, Bassaris H, et al. Prevalence of hepatitis $\mathrm{B}$ and $\mathrm{C}$ virus infection in the general population and selected groups in South-Western Greece. European journal of epidemiology. 2003;18(6):551-7. 
Table 1: Demographic characteristics and risk of having disease in the subjects

\begin{tabular}{|c|c|c|c|}
\hline \multicolumn{2}{|c|}{ Parameters } & Frequency & Percent \\
\hline \multirow[b]{2}{*}{ Gender } & Male & 97 & 55.7 \\
\hline & Female & 77 & 44.3 \\
\hline \multirow[b]{2}{*}{ Local } & Urban & 90 & 51.7 \\
\hline & Rural & 84 & 48.3 \\
\hline \multirow{5}{*}{ Education } & Uneducated & 35 & 20.1 \\
\hline & Primary & 37 & 21.3 \\
\hline & High school & 37 & 21.3 \\
\hline & Diploma & 30 & 17.2 \\
\hline & Post-diploma & 35 & 20.1 \\
\hline \multirow{2}{*}{ Nationality } & Iranian & 167 & 96 \\
\hline & Non-Iranian & 7 & 4 \\
\hline \multirow[b]{2}{*}{ Indigenous } & Yes & 130 & 74.7 \\
\hline & No & 44 & 253 \\
\hline \multirow{7}{*}{ Profession } & Housewives & 3 & 1.7 \\
\hline & Self-employed & 53 & 30.5 \\
\hline & Employee & 8 & 4.6 \\
\hline & University Student & 2 & 1.1 \\
\hline & School Student & 2 & 1.1 \\
\hline & Jobless & 96 & 55.2 \\
\hline & Retired & 10 & 5.7 \\
\hline \multirow{3}{*}{ Marital status } & Single & 30 & 17.2 \\
\hline & Married & 141 & 81 \\
\hline & Divorced & 3 & 1.7 \\
\hline
\end{tabular}


Table 2: Age frequency distribution of participants

\begin{tabular}{ccc}
\hline Age Groups & Number & Percent \\
\hline $15-24$ & 14 & 8 \\
$25-34$ & 47 & 27 \\
$35-44$ & 41 & 23.6 \\
$45-54$ & 26 & 14.9 \\
$55-64$ & 26 & 14.9 \\
$\geq 65$ & 20 & 11.5 \\
\hline
\end{tabular}

Table 3: Anthropometric indices and risk of developing disease in subjects

\begin{tabular}{cccc}
\hline Parameters & CHB $(\mathbf{n = 1 7 4})$ & Control $(\mathbf{n = 1 0 4})$ & P Value \\
\hline Weight & $69.60 \pm 13.79$ & $70.48 \pm 12.84$ & 0.629 \\
Height & $168.85 \pm 7.82$ & $166.99 \pm 7.79$ & 0.084 \\
Wasit & $87.48 \pm 13.79$ & $85.75 \pm 13.41$ & 0.356 \\
Hip & $98.33 \pm 11.48$ & $99.03 \pm 13.51$ & 0.683 \\
BMI & $24.33 \pm 4.30$ & $25.26 \pm 3.79$ & 0.102 \\
WHR & $0.89 \pm 0.09$ & $0.87 \pm 0.08$ & 0.124 \\
\hline
\end{tabular}


Table 4: BMI and WHR frequency distribution of participants

\begin{tabular}{ccccc}
\hline & & CHB $(\mathbf{n}=\mathbf{1 7 4})$ & Control $(\mathbf{n = 1 0 4})$ & P Value \\
\hline BMI & $18.5>$ & 15 & 4 & \\
Groups & $25-29.9$ & 60 & 44 & 0.375 \\
& $>30$ & 19 & 40 & \\
& $0.80 \geq$ & 25 & 16 & 0.592 \\
WHR & $0.81-0.85$ & 10 & 12 & \\
Groups & $>0.85$ & 36 & 27 & \\
(Female- & $0.95 \geq$ & 72 & 36 & \\
Male) & $0.96-1.00$ & 15 & 7 & 7 \\
& $>1.00$ & 16 & & 76
\end{tabular}


Table 5: Possible risk factors among HBV seropositive individuals.

\begin{tabular}{lcc}
\hline Risk Factor & Frequency & Percent \\
\hline Intravenous drug use & 4 & 2.3 \\
Rpregnancy & 23 & 13.2 \\
Vertical Transmission & 21 & 12.1 \\
Family history of HBV positive in patients & 46 & 26.4 \\
History Dialises & 0 & 0 \\
Jail & 4 & 2.3 \\
Tattooing & 3 & 1.7 \\
Piercing & 14 & 8 \\
History of hairdressers & 56 & 32.2 \\
Endoscopy & 19 & 10.9 \\
Colonoscopy & 2 & 1.1 \\
Surgery & 21 & 12.1 \\
Dentist visit & 46 & 26.4 \\
Water pipe & 21 & 12.1 \\
Smoking & 17 & 9.8 \\
Alcohol cosumpsion & 0 & 0 \\
Vaccination history & 53 & 30.5 \\
Hospitalization & 4 & 2.3 \\
HIV disease in patients at the same time & 0 & 0 \\
HCV disease in patients at the same time & 0 & 0 \\
Family history of HIV positive in patients & 0 & 0 \\
Family history of HCV positive in patients & 0 & 0 \\
Phlebotomy (Hejamat) & 0 & 0 \\
Needle stick & 1 & 0.6 \\
Addiction & 4 & 2.3 \\
Health workers & 9 & 5.2 \\
Contact with suspected HBV persons & 52 & 4.6 \\
Blood transfusion and blood products history & 8 & 1.1 \\
Injection Drug Addicts & 2 & 2.9 \\
Unsafe sexual practices and dubious & 5 & \\
\hline
\end{tabular}

